\title{
PERANAN KEGIATAN KAJI TERAP TERHADAP PENINGKATAN PENGETAHUAN DAN SIKAP PENYULUH PERTANIAN DALAM TEKNOLOGI PENGELOLAAN TANAMAN TERPADU CABAI
}

\section{The Role of Application Study of Application to Increasing Knowledge and Attitudes of Agricultural Extension In Integrated Plant Management Technology of Chili}

\author{
Eko Nugroho Jati*, Jemmy Rinaldi, I Nyoman Adijaya \\ Balai Pengkajian Teknologi Pertanian Bali \\ *Email: ekograndis@gmail.com
}

\begin{abstract}
In the process of disseminating technological innovation, there is still an information gap between providers of technological innovation, namely the Agricultural Research Agency and regional agricultural stakeholders and farmers. Agricultural Research and Development Agency has produced many agricultural technological innovations, one of which is technological innovation to overcome obstacles in the cultivation of chili is the Integrated Crop Management (PTT) Chili technology. One way to overcome the problem of inaction in the application of technological innovations produced is one of them is an applied review activity targeting Agricultural Extension Workers in the regions. This study aims to: determine the increase in knowledge and attitudes of Agricultural Instructors in PTT Cabai Rawit technology through applied study activities. The study was conducted at the Agricultural Counseling Center (BPP) of Banjarangkan District, Klungkung Regency with a survey method of 20 agricultural extension respondents using a questionnaire. Data were analyzed descriptively quantitatively. The results of the study show that: Applied Study Activities have an impact on changes in knowledge and agricultural extension cycle in PTT Cabai technology, namely Agricultural Extension knowledge changed from an average score of 2.04 (medium knowledge) to an average score of 2.89 (high knowledge) and attitudes of farmers from an average score of 2.31 (doubtful attitude) to an average score of 2.81 (agreeing attitude).
\end{abstract}

Keywords: Applied assessment, knowledge, attitude, chili

\begin{abstract}
ABSTRAK
Dalam proses diseminasi inovasi teknologi masih terdapat kesenjangan informasi antara penyedia inovasi teknologi yaitu Badan Litbang Pertanian dengan pemangku kepentingan pertanian di daerah dan petani. Badan Litbang Pertanian telah banyak menghasilkan inovasi teknologi pertanian, salah satunya Inovasi teknologi untuk mengatasi kendala dalam budidaya cabai adalah teknologi Pengelolaan Tanaman Terpadu (PTT) Cabai. Langkah untuk mengatasi masalah kelambanan dalam penerapan inovasi teknologi yang dihasilkan salah satunya yaitu dengan kegiatan kaji terap dengan sasaran Penyuluh Pertanian di daerah. Penelitian ini bertujuan untuk: mengetahui peningkatan pengetahuan dan sikap Penyuluh Pertanian dalam teknologi PTT Cabai Rawit melalui kegiatan kaji terap. Penelitian dilakukan di Balai Penyuluhan Pertanian (BPP) Kecamatan Banjarangkan, Kabupaten Klungkungdengan metode survey terhadap 20penyuluh pertanian responden menggunakan kuesioner. Data dianalisis secara deskriptif kuantitatif. Hasil kajian memperlihatkan bahwa: Kegiatan Kaji Terap memberikan dampak terhadap perubahan pengetahuan dan sikappenyuluh pertanian dalam teknologi PTT Cabai, yaitu pengetahuan Penyuluh Pertanian berubah dari rata-rata score 2.04 (pengetahuan sedang) menjadi rata-rata score 2.89 (pengetahuan tinggi) dan sikap petani dari rata-rata score 2.31 (sikap ragu-ragu) menjadi rata-rata score 2.81 (sikap setuju).
\end{abstract}

Kata Kunci: Kaji terap, pengetahuan, sikap, cabai 


\section{PENDAHULUAN}

Badan Penelitian dan Pengembangan Pertanian (Badan Litbang Pertanian) telah menghasilkan berbagai teknologi pertanian, namun teknologi tersebut belum sepenuhnya dapat diadopsi oleh pengguna (sasaran). Salah satu penyebabnya adalah kurang tepatnya bentuk diseminasi yang digunakan dalam proses alih teknologi. Selain itu, penelitian dan pengkajian yang dilakukan oleh Badan Litbang pertanian, sering kurang sejalan dengan kebutuhan teknologi di tingkat lapangan. Oleh karena itu perlu dilakukan upaya untuk mempercepat transfer teknologi tersebut kepada petani sebagai pengguna melalui berbagai bentuk diseminasi, sesuai dengan tujuan yang ingin dicapai.Pada tahun 2018, Balai Pengkajian Teknologi Pertanian (BPTP) Bali melaksanakan kegiatan yang bertujuan untuk mempercepat proses alih teknologi pertanian yang dihasilkan Badan Litbang Pertanian, melalui metode diseminasi Kaji Terap. Selain itu kegiatan tersebut juga bertujuan untuk mendapatkan umpan balik dari pengguna mengenai paket teknologi yang dihasilkan oleh Badan Litbang Pertanian.

Untuk meyakinkan stakeholders dan pembuktian keunggulan inovasi Badan Litbang Pertanian, dilakukan dengan kegiatan kaji terap inovasi pertanian yang dilaksanakan di lokasi yang mempunyai potensi dan prospektif untuk pengembangan dari muatan isi atau inovasi kegiatan kaji terap tersebut. Lokasi kaji terap berfungsi juga sebagai media diseminasi, pembelajaran, dan konsultasiteknologi. Selain itu pada lokasi kajiterap merupakan wahana interaksi antara peneliti, penyuluh, petani, dan stakeholders lainnya untuk mendiskusikan dan mencari penyelesaian terhadap permasalahan usaha pertanian.Menurut Kushartanti et al. (2018) Kaji terapadalah ujicoba teknologi yang dilakukan oleh pelaku utama untuk meyakinkan keunggulan teknologi anjuran dibandingkan teknologi yang pernah diterapkan, sebelum diterapkan atau dianjurkan kepada pelaku utama lainnya.

Inovasi teknologi Badan Litbang Pertanian untuk mengatasi masalah budidaya cabai yaitu teknologi Pengelolaan Tanaman Terpadu (PTT). Pengelolaan Tanaman Terpadu merupakan suatu pendekatan budidaya tanaman yang berdasarkan pada keseimbangan ekonomi dan ekologi, dengan tujuan utamanya adalah meraih keseimbangan antara pengeluaran dan pendapatan, antara proses alami dan teknologi, dengan selalu mengingat keberlanjutan dari usahatani tersebut (Setiawati, 2010).

Untuk itu pada tahun 2018 BPTP Bali mengimplementasikan teknologi PTT cabai pada kegiatan kaji terap. Melalui upaya tersebut diharapkan adopsi inovasi teknologi hasil litkaji Badan Litbang Pertanian akan semakin cepat, yang merupakan salah satu indikator penting keberhasilan Badan Litbang Pertanian dalam menghasilkan teknologi pertanian innovative.

Penelitian ini bertujuan untuk: mengetahui peningkatan pengetahuan dan sikap Penyuluh Pertaniandalam teknologi PTT Cabai Rawit melalui kegiatan kaji terap.

\section{METODE}

Penelitian ini dilaksanakan di Balai Penyuluhan Pertanian (BPP) Kecamatan Banjarangkan, Kabupaten Klungkung dengan pertimbangan merupakan kawasan pengembangan kawasan komoditas cabai. Data sebelum dan sesudah kegiatan kaji terap dikumpulkan melalui survey menggunakan kuesioner terhadap 20 orang penyuluh pertanian sampel pada Tahun 2018.

Analisis data dilakukan pertanyaan-pertanyaan dikelompokkan berdasarkan kategori dan dipersentasekan, analisis data dengan menggunakan matriks dan membuat kesimpulan umum berupa paparan sederhana.Pengetahuan dan sikap petani diukur terhadap teknologi pengelolaan tanaman terpadu (PTT) cabai yang dilihat berdasarkan beberapa komponen, yaitu: (1) varietas unggul baru, (2) perlakuan benih, (3) persemaian, (4) induksi, (5) pembuatan bedengan, (5) MPHP, (6) pupuk dasar organik, (7) pupuk dasar organik, (8) pupuk dasar kimia, (9) dolomit, (10) tanaman barrier, (11) penanaman bibit, (12) jarak tanam, (13) pengairan, (14) pemupukan kocor, (15) pemasangan ajir, (16) pewiwilan, (17) pestisida nabati, (18) perangkap kuning, dan (19) panen tepat waktu. Pengkategorian menggunakan rumus interval (Dajan, 1996).

$$
\mathrm{I}=\frac{J}{K}
$$

Dimana:

I $\quad=$ Interval kelas

J = Jarak antara skor maksimum dan skor minimum

$\mathrm{K}$ = Banyaknya kelas yang digunakan

Pengukuran dari masing-masing komponen teknologi PTT cabai diukur berdasarkan tiga klasifikasi yaitu, rendah, sedang dan tinggi berdasarkan skor yang diperoleh yang dihitung berdasarkan nilai pengetahuan dan sikap masingmasing indikator yang diukur. Untuk masingmasing komponen diukur dari nilai score 1,003,00. Klasifikasi score per komponen teknologi yaitu, rendah $(1,00-1,66)$, sedang $(1,67-2,33)$ dan tinggi $(2,34-3,00)$.

Untuk melihat perubahan pengetahuan dan sikap petani terhadap komponen teknologi PTT dilakukan pengujian menggunakan uji nonparametrik (Wilcoxon Signed Rank Test) yang tersedia dalam program SPSS 20. 


\section{HASIL DAN PEMBAHASAN}

\section{Perubahan Pengetahuan Penyuluh Pertanian}

Misi terpenting dari kegiatan diseminasi yaitu mengubah perilaku sasaran agar mereka tahu dan mampu menerapkan inovasi teknologi. Pengetahuan merupakan tahap awal terjadinya persepsi yang kemudian membentuk sikap dan pada akhirnya menciptakan perbuatan atau tindakan. Menurut Sudarta (2002) bahwa, dalam akselerasi pembangunan pertanian, pengetahuan mempunyai arti penting karena pengetahuan dapat mempertinggi kemampuan dalam mengadopsi teknologi baru di bidang pertanian. Setiap individu mempunyai kemampuan berbeda untuk mengembangkan pengetahuannya, karena sasaran penyuluhan sangatlah beragam yaitu dalam hal karakteristik individu, lingkungan fisik dan sosialnya, kebutuhannya, motivasi serta tujuan yang diinginkan. Pengetahuan Penyuluh Pertanian di BPP Banjarangkansebelum dan sesudah kegiatan kaji terap terhadap teknologi PTT Cabai dapat dilihat pada tabel 1 berikut.

Tabel 1.Pengetahuan Penyuluh Pertanian Sebelum dan Sesudah Kegiatan Kaji Terap terhadap Teknologi Pengelolaan Tanaman Terpadu (PTT) Cabai di BPP Banjarangkan, Kabupaten Klungkung Tahun 2018.

\begin{tabular}{|c|c|c|c|c|c|}
\hline \multirow{2}{*}{ Komponen Teknologi } & \multicolumn{2}{|c|}{$\begin{array}{c}\text { Rata-rata Score Pengetahuan } \\
\text { Penyuluh } \\
\end{array}$} & \multicolumn{3}{|c|}{$\begin{array}{c}\text { Perubahan Pengetahuan Penyuluh } \\
\text { (Orang) }\end{array}$} \\
\hline & Awal & Akhir & Positif & Negatif & Ties \\
\hline Varietas Unggul Baru & $1.00^{\mathrm{a}}$ & $2.85^{\mathrm{b}}$ & 20 & & \\
\hline Perlakuan Benih & $1.30^{\mathrm{a}}$ & $2.90^{\mathrm{b}}$ & 20 & & \\
\hline Persemaian & $1.95^{\mathrm{a}}$ & $2.85^{\mathrm{b}}$ & 12 & & 8 \\
\hline Induksi & $1.00^{\mathrm{a}}$ & $2.80^{\mathrm{b}}$ & 19 & & 1 \\
\hline Pembuatan Bedengan & $2.95^{\mathrm{a}}$ & $2.95^{\mathrm{a}}$ & & & 20 \\
\hline MPHP & $2.50^{\mathrm{a}}$ & $2.90^{\mathrm{b}}$ & 8 & & 12 \\
\hline Pupuk Dasar Organik & $2.25^{\mathrm{a}}$ & $2.85^{\mathrm{b}}$ & 12 & & 8 \\
\hline Pupuk Dasar Kimia & $1.70^{\mathrm{a}}$ & $2.85^{\mathrm{b}}$ & 17 & & 3 \\
\hline Dolomit & $2.50^{\mathrm{a}}$ & $2.90^{\mathrm{b}}$ & 8 & & 12 \\
\hline Tanaman Barrier & $1.20^{\mathrm{a}}$ & $2.95^{\mathrm{b}}$ & 17 & & 3 \\
\hline Penanaman Bibit & $2.60^{\mathrm{a}}$ & $2.80^{\mathrm{b}}$ & 4 & & 16 \\
\hline Jarak Tanam & $2.60^{\mathrm{a}}$ & $2.90^{\mathrm{b}}$ & 6 & & 14 \\
\hline Pengairan & $2.75^{\mathrm{a}}$ & $3.00^{\mathrm{b}}$ & 5 & & 15 \\
\hline Pemupukan Kocor & $1.70^{\mathrm{a}}$ & $2.85^{\mathrm{b}}$ & 12 & & 8 \\
\hline Pemasangan Ajir & $2.75^{\mathrm{a}}$ & $2.95^{\mathrm{b}}$ & 4 & & 16 \\
\hline Pewiwilan & $1.65^{\mathrm{a}}$ & $2.80^{\mathrm{b}}$ & 14 & & 6 \\
\hline Pestisida Nabati & $1.30^{\mathrm{a}}$ & $2.90^{\mathrm{b}}$ & 19 & & 1 \\
\hline Perangkap Kuning & $2.30^{\mathrm{a}}$ & $2.85^{\mathrm{b}}$ & 7 & & 13 \\
\hline Panen Tepat Waktu & $2.75^{\mathrm{a}}$ & $3.00^{\mathrm{b}}$ & 5 & & 15 \\
\hline Rata-rata Score & 2.04 & 2.89 & & & \\
\hline Kategori & Sedang & Tinggi & & & \\
\hline
\end{tabular}

Berdasarkan Tabel 1, secara keseluruhan pada awal kegiatan pengetahuan penyuluh pertanian berada pada kategori sedang (score 2.04), hal ini disebabkan karena belum tersosialisasikannya semua komponen teknologi PTT cabai secara menyeluruh, walaupun secara umum petani di wilayah kerja BPP Banjarangkan mengusahakan tanaman cabai, namun penyuluh pertanian di BPP Banjarangkan secara keseluruhan belum mengetahui komponen teknologi PTT Cabai yang baik dan benar sesuai dengan rekomendasi Badan Litbang Pertanian.

Pada akhir kegiatan menunjukkan bahwa pelaksanaan display teknologi dan kaji terap teknologi PTT Cabai telah berjalan sesuai dengan harapan, pencapaian sasaran kegiatan ditandai dengan adanya peningkatan pengetahuan penyuluh pertanian menjadi tinggi (score 2.89) setelah kegiatan kaji terap. Peningkatan pengetahuan paling besar terjadi pada komponen teknologi: 
varietas unggul baru, perlakuan benih, induksi, dan pestisida nabati. Sedangkan pada komponen teknologi pembuatan bedengan pengetahuan penyuluh cenderung tetap/tidak berubah, hal ini disebabkan dari awal kegiatan tingkat pengetahuan penyuluh mengenai pembuatan bedengan sudah tinggi.

Pengetahuan pada komponen teknologi varietas unggul baru perubahannya besar yaitu meningkat positif sebanyak 20 orang hal ini disebabkan pada awal kegiatan penyuluh pertanian hanya mengetahui varietas cabai rawit lokal Klungkung (Bontok) yang biasa diusahakan petani di Banjarangkan yang diperoleh dari hasil panen sebelumnya. Hal ini yang mengakibatkan produktivitas cabai rawit yang dihasilkan sebagian besar petani hanya sebesar 5-6 ton/ha. Padahal potensi produktivitas yang dapat dihasilkan jika menggunakan varietas unggul mampu berproduksi sebesar 10-20 ton/ha (Ditjen Bina Produksi Hortikultura, 2010). Artinya masih ada kesenjangan produksi yang dihasilkan petani sekitar 5-14 ton/ha. Menurut Sumarni et al (2005) bahwa pemilihan varietas sangat penting untuk menyesuaikan dengan kondisi lahan dan kebutuhan pasar. Pemilihan varietas unggul baru dalam PTT cabai bertujuan untuk: mendapatkan daya hasil tinggi, sesuai selera konsumen/ pasar, toleran terhadap hama dan penyakit, mampu beradaptasi dengan baik pada lokasi spesifik. Pada kegiatan Kaji Terap penyuluh pertanian dikenalkan dengan varietas unggul baru cabai rawit hasil Badan Litbang pertanian yaitu varietas Rabbani Agrihorti yang mempunyai potensi hasil $4,16-13.8$ ton/ha.

Pada komponen teknologi perlakuan benih, induksi, dan pestisida nabati pengetahuan petani meningkat positif sebanyak 19 orang dan 20 orang. Hal ini dikarenakan salah satu materi dalam kegiatan bimbingan teknis yaitu pengendalian hama dan penyakit pada tanaman cabai. Petani diajarkan mengenai cara pembuatan induksi cabai menggunakan ekstrak daun bunga pukul empat dan pestisida nabati Kisela 866 yang kemudian diaplikasikan pada tanaman cabai di lokasi demplot. Metode penyampaian materi yang digunakan yaitu ceramah dan demonstrasi cara. Dengan metode demonstrasi cara penyuluh diajak untuk memperagakan/mempraktekkan langsung pembuatan induksi ektrak daun bunga pukul empat dan pestisida nabati Kisela 866, sehingga penyuluh memperoleh gambaran langsung mengenai pembuatan induksi dan pestisida nabati.
Pengetahuan sangat membantu dan menunjang kemampuan untuk mengadopsi teknologidalam usahataninya dan kelanggengan usahataninya (Sudarta, 2002). Semakin tinggi tingkat pengetahuan maka kemampuandalam mengadopsi teknologi juga tinggi. Dengan meningkatnya pengetahuan penyuluh diharapkan proses transfer teknologi PTT Cabai dengan cepat dapat diadopsi oleh petani.

Peningkatan pengetahuan penyuluh tidak terlepas dari peran narasumber yang berkompeten dalam materi PTT Cabai. Narasumber merupakan peneliti dari Balai Pengkajian Teknologi Pertanian (BPTP) Bali. Sebagaimana yang disampaikan oleh Haslinda et al. (2009) bahwa, kompetensi narasumber merupakan faktor yang signifikan berkontribusi terhadap efektivitas penyuluhan. Karakteristik petani juga merupakan faktor penting yang berpengaruh dalam meningkatnya pengetahuan petani. Sebagaimana yang disampaikan BBP2TP (2014) bahwa, faktor-faktor yang mempengaruhi pengetahuan antara lain pendidikan, pekerjaan, umur, minat, pengetahuan dan informasi.

Sikap merupakan potensi pendorong yang ada pada individu untuk bereaksi terhadap lingkungan. Sikap (attitude) merupakan kemampuan internal yang berperan sekali dalam mengambil tindakan, orang memiliki sikap yang jelas mampu untuk memilih dengan tegas diantarabeberapakemungkinan atau tersedianya beberapa alternative. Orang yang bersikap tertentu cenderung menerima atau menolak suatu objek berdasarkan penilaian terhadap objek itu berguna/ berharga bagi dirinya atau tidak (Winkel, 1987). Sikap tidak selamanya tetap dalam jangka waktu tertentu tetapi dapat berubah karena pengaruh orang lain melalui interaksi sosial. Dalam interaksi sosial, terjadi hubungan saling mempengaruhi diantara individu yang satu dengan yang lain. Individu bereaksi membentuk pola sikap tertentu terhadap berbagai objek psikologis yang dihadapinya. Diantara berbagai faktor yang mempengaruhi pembentukan sikap adalah pengalaman pribadi, kebudayaan, orang lain yang dianggap penting, media massa, institusi atau lembaga pendidikan dan lembaga agama, serta faktor emosi didalam diri individu (Azwar, 2000). Sikap yang diperoleh lewat pengalaman akan menimbulkan pengaruh langsung terhadap perilaku.Perubahan sikap penyuluh pertanian dalam PTT Cabai di BPP Kecamatan Banjarangkan, Kabupaten Klungkung dapat dilihat pada Tabel 2 berikut. 
Tabel 2.Sikap Penyuluh Pertanian Sebelum dan Sesudah Kegiatan Kaji Terap terhadap Teknologi Pengelolaan Tanaman Terpadu (PTT) Cabai di BPP Banjarangkan, Kabupaten Klungkung Tahun 2018.

\begin{tabular}{|c|c|c|c|c|c|}
\hline \multirow{2}{*}{ Komponen Teknologi } & \multicolumn{2}{|c|}{$\begin{array}{c}\text { Rata-rata Score Pengetahuan } \\
\text { Penyuluh }\end{array}$} & \multicolumn{3}{|c|}{$\begin{array}{l}\text { Perubahan Pengetahuan } \\
\text { Penyuluh (Orang) }\end{array}$} \\
\hline & Awal & Akhir & Positif & Negatif & Ties \\
\hline Varietas Unggul Baru & $1.05^{\mathrm{a}}$ & $1.15^{\mathrm{a}}$ & 1 & & 19 \\
\hline Perlakuan Benih & $2.45^{\mathrm{a}}$ & $2.95^{\mathrm{b}}$ & 10 & & 10 \\
\hline Persemaian & $2.50^{\mathrm{a}}$ & $2.95^{\mathrm{b}}$ & 9 & & 11 \\
\hline Induksi & $2.15^{\mathrm{a}}$ & $3.00^{\mathrm{b}}$ & 17 & & 3 \\
\hline Pembuatan Bedengan & $2.85^{\mathrm{a}}$ & $2.95^{\mathrm{a}}$ & 2 & & 18 \\
\hline MPHP & $1.85^{\mathrm{a}}$ & $2.90^{\mathrm{b}}$ & 18 & & 2 \\
\hline Pupuk Dasar Organik & $2.80^{\mathrm{a}}$ & $2.95^{\mathrm{a}}$ & 3 & & 17 \\
\hline Pupuk Dasar Kimia & $2.70^{\mathrm{a}}$ & $2.95^{\mathrm{b}}$ & 5 & & 15 \\
\hline Dolomit & $2.55^{\mathrm{a}}$ & $2.95^{\mathrm{b}}$ & 8 & & 12 \\
\hline Tanaman Barrier & $1.75^{\mathrm{a}}$ & $2.95^{\mathrm{b}}$ & 19 & & 1 \\
\hline Penanaman Bibit & $2.70^{\mathrm{a}}$ & $2.90^{\mathrm{b}}$ & 4 & & 16 \\
\hline Jarak Tanam & $2.60^{\mathrm{a}}$ & $3.00^{\mathrm{b}}$ & 8 & & 12 \\
\hline Pengairan & $2.90^{\mathrm{a}}$ & $3.00^{\mathrm{a}}$ & 2 & & 18 \\
\hline Pemupukan Kocor & $2.30^{\mathrm{a}}$ & $2.95^{\mathrm{b}}$ & 13 & & 7 \\
\hline Pemasangan Ajir & $2.85^{\mathrm{a}}$ & $3.00^{\mathrm{a}}$ & 3 & & 17 \\
\hline Pewiwilan & $1.25^{\mathrm{a}}$ & $2.90^{\mathrm{b}}$ & 19 & & 1 \\
\hline Pestisida Nabati & $1.80^{\mathrm{a}}$ & $2.00^{\mathrm{b}}$ & 4 & & 16 \\
\hline Perangkap Kuning & $1.90^{\mathrm{a}}$ & $2.95^{\mathrm{b}}$ & 19 & & 1 \\
\hline Panen Tepat Waktu & $2.90^{\mathrm{a}}$ & $3.00^{\mathrm{a}}$ & 2 & & 18 \\
\hline Rata-rata Score & 2.31 & 2.81 & & & \\
\hline Kategori & Ragu-ragu & Setuju & & & \\
\hline
\end{tabular}

Berdasarkan Tabel 2, bahwa pada akhir kegiatan menunjukkan bahwa pelaksanaan display teknologi dan kaji terap teknologi PTT Cabai telah berjalan sesuai dengan harapan, pencapaian sasaran kegiatan ditandai dengan adanya peningkatan sikap penyuluh pertanian setelah kegiatan kaji terap yaitu dari sikap ragu-ragu (score 2.31) menjadi setuju setuju (score 2.81). Peningkatan sikap paling besar terjadi pada komponen teknologi: tanaman barrier, pewiwilan, dan perangkap kuning.

\section{SIMPULAN}

Berdasarkan hasil analisis kajian mengenai perubahan pengetahuan dan sikap penyuluh pertanian dalam Pengelolaan Tanaman Terpadu (PTT) cabai rawit disimpulkan bahwa: Kegiatan kaji terap berperan dalam perubahan pengetahuan dan sikap penyuluh pertanian, yaitu pengetahuan Penyuluh Pertanian berubah dari pengetahuan sedang menjadi pengetahuan tingg dan sikap petani dari sikap ragu-ragu menjadi sikap setuju.

\section{DAFTAR PUSTAKA}

Azwar, S. 2000. Sikap Manusia Teori dan Pengukurannya. Pustaka Pelajar. Yogyakarta.

Balai Besar Pengkajian dan Pengembangan Teknologi Pertanian (BBP2TP). 2014. Panduan Pelaksanaan dan Kumpulan Materi Training of Trainer (TOT) "Metodologi Pengkajian Penyuluhan dan Evaluasi Kinerja Hasil Litkaji bagi Penyuluh Pertanian Lingkup BBP2TP. Kementerian Pertanian, Jakarta.

Dajan, A. 1996.Pengantar Metode Statistik. Jilid II. Penerbit LP3ES. Jakarta. 
Direktur Jendral Bina Produksi Hortikultura. 2010. Statistik Hortikultura tahun 2010. Dirjen Hortikultura, Departemen Pertanian, Jakarta 125 hal.

Haslinda, A. Mahyuddin, MY. 2009. The Effectivenes of Training in the Public Service. Amer J Sci 6(1). hlm. 39-51.

Kushartanti, E. Retno, DW. Umi, PA. Rahima, K. Tini, SK. Sad, HP. Muchamad, Y. Sumedi. Mewa, A. Maesti, M. Achmad, D. Rachmat, H. 2018. Pedoman Pelaksanaan Peningkatan Kapasitas Penyuluh dan Diseminasi Inovasi Pertanian.Badan Penelitian dan Pengembangan Pertanian, Jakarta.

Setiawati, W. 2010.Modul Pelatihan SL-PTT Cabai Merah-Bawang Merah.Pusat Penelitian dan Pengembangan Hortikultura, Badan Penelitian dan Pengembangan Pertanian, Kementerian Pertanian.

Sudarta, W. 2002. Pengetahuan dan Sikap Petani Terhadap Pengendalian Hama Terpadu. Jurnal Sosial Ekonomi Pertanian dan Agribisnis 2(1). Januari 2002. Fakultas Pertanian Universitas Udayana. hlm. 3134.

Sumarni, N. Agus, M. 2005. Budidaya Tanaman Cabai Merah. Balai Penelitian Tanaman Sayuran. Bandung.

Winkel,WS. 1987. PsikologiPengajaran. Gramedia, Jakarta. 